\title{
The effects of Alginite fertilization on selected tree species seedlings performance on afforested agricultural lands
}

\author{
Jan Cukor, Lukáš Linhart*, Zdeněk Vacek, Martin Baláš, Rostislav Linda \\ Czech University of Life Sciences Prague, Faculty of Forestry and Wood Sciences, Kamýcká 129, \\ CZ-165 21 Prague 6-Suchdol, Czech Republic
}

\begin{abstract}
Afforestation of marginal agricultural lands is an important issue in the land use changes running in Europe at present. The aim of the presented study is the documentation of effects of site improving material Alginite three years after afforestation of agricultural land in the locality with unfavourable hydrophysical regime. The impact was evaluated on growth parameters (height increment, mortality and foliar nutrient content) of Douglas fir (Pseudotsuga menziesii (Mirb.) Franco), Scots pine (Pinus sylvestris L.) and a mixture of English oak (Quercus robur L.), red oak (Quercus rubra L.) and Norway maple (Acer platanoides L.) seedlings on former agricultural land in central Bohemia, Czech Republic. The research plot consists of 36 square sub-plots, each sub-plot is $400 \mathrm{~m}^{2}$ in size. Each sub-plot consists of 400 individuals, except Douglas-fir with 200 individuals. The following doses of Alginite were applied: control (variant A without Alginite), $0.5 \mathrm{~kg}$ of Alginite (B) and $1.5 \mathrm{~kg}$ of Alginite (C) on both conifers and broadleaves. The results showed that Alginite application had greater positive effect on height growth of seedlings than mortality, especially variant $C$. In most of the cases height increments were significantly positively affected $(p<0.05)$ by both variants of Alginite application only in the third year after planting. Alginite applications were also connected with differences in the foliar nutrient content, especially with higher magnesium and phosphorus values. The highest differences among Alginite variants were observed for Norway maple and English oak, while the lowest for red oak and Scots pine within all monitored parameters.
\end{abstract}

Key words: afforestation; soil improvement; fertiliser; plantation growth; mortality

Editor: Vladimír Šebeň

\section{Introduction}

Changes of the land use are continuously running in the Europe for centuries (Skaloš et al. 2012). From a historical perspective, the population of Central Europe has been engaged in reforestation of agricultural land for at least two centuries (Špulák \& Kacálek 2011). This trend reversed tendencies common in the previous period, causing deforestation for the purpose of obtaining fuel, construction materials, but also for gaining the land suitable for agricultural use (Kaplan et al. 2009; Williams 2000), throughout the whole European continent (Rowney 2015). Although some evidence on the reforestation of non-forest lands are dated in the $16^{\text {th }}$ century (Kacálek \& Bartoš 2002; Špulák 2006), the largest expansion of afforestation of agricultural land was not until after the Second World War (Kacálek \& Bartoš 2002), especially in the border regions after the confiscation of grounds originally belonging to the German population (Špulák \& Kacálek 2011; Vacek et al. 2016). In the sixties of the $20^{\text {th }}$ century afforestation of non-forest land reached up to 6,000 hectares peryear, later on annually around 1,000 hectares (Černý et al. 1995). Another phase of afforesta- tion and forest expansion comes in the 1990s and is still under way (Špulák \& Kacálek 2011). Nowadays (from 2010 to 2014) forest area in the Czech Republic increased by 2,250 ha year ${ }^{-1}$ (MZe 2015).

Large areas of agricultural land suitable for afforestation are not found only in Eastern Europe (Henebry 2009) and in some parts of Western Europe (Anthelem et al. 2001), but currently also in the Czech Republic. More exact estimates are depending on the used criteria, for example Podrázský \& Štěpaník (2002) have reported between 50,000 to 500,000 hectares. In the area of the European Union there is cca 12 to 16 million ha of land to be excluded from agricultural production and thus suitable for afforestation from ecological as well as economic reasons (Campbell et al. 2008). It is therefore important to pay a great attention to this issue.

The most frequently used tree species in the newly established forest stands was Norway spruce (Picea abies [L.] Karst.), but also other specimen such as European larch (Larix decidua Mill.), black alder (Alnus glutinosa L. Gaertn.), European ash (Fraxinus excelsior L.) and Scots pine (Pinus sylvestris L.) (Hatlapatková et al. 2006; Šindelář \& Frýdl 2006; Vacek et al. 2015, 2016). Intro- 
duced tree species such as Douglas fir (Pseudotsugamenziesii Mirbat.) or red oak (Quercus rubra L.) have been recently gaining attention (Gruber \& Nick 2000; Miltner $\&$ Kupka 2016). Those are also used in afforestation of former agricultural land.

The most problematic stage in the establishment and development of forest stands, particularly in extreme climatic and habitat conditions, is undoubtedly the phase of actual planting. Survival rate and initial growth of established stands determines further development of plantations (Kupka et al. 2015). Failures in reforestation are often affected by unfavourable soil conditions. However, forest species have various mechanisms allowing successful growth under unfavorable habitat conditions (Vacek \& Hejcman 2012; Vacek et al. 2012). On the other hand, there is thus many practices designed to facilitate reforestations used in forestry, categorized as chemical or biological amelioration (Podrázský 1994, 2006a, b; Podrázský et al. 2003; Kacálek et al. 2009; Balcar et al. 2011; Kuneš et al. 2011). These interventions may involve the application of lime, pulverized basic rocks (Kuneš et al. 2009) or special slowly soluble fertilizers (Kuneš et al. 2004). Furthermore, a number of deciduous trees has beneficial effect on the state of forest soils in mountain conditions (Podrázský et al. 2004).

One of the important factors ensuring successful reforestation and decent survival rate of young trees is undoubtedly soil moisture in the upper horizon of the soil profile. Moisture deficiency in the soil negatively affects root system. This problem may be partially mitigated by adding fossil materials such as Alginite (Kupka et al. 2015), which, besides, have the function of enhancing water uptake in the root area of the seedlings.

Alginite is an organic sediment representing the oil shale category, which was formed 3-4 million years ago during volcanic changes (Kulich et al. 2001; Kadar et al. 2015). This gray to dark gray rock is rich in organic matter and contains 5 to $50 \%$, in some deposits even $90 \%$ of organic matter (Szabó 2004). Alginite was created in aquatic environment of algae and therefore performs a high content of elements such as phosphorus, potas sium, calcium and magnesium (Gömöryová et al. 2009). Vass et al. (1997, 1998) formerly described the use of Alginite in forestry. The effect on seedlings in the first year after afforestation of agricultural land was assessed by Tužinský et al. (2015) and Kupka et al. (2015).

This study is focused on the afforestation of nonforest land in areas less favourable for forest tree species and documents the effects of Alginite fertilization on plantations survival rate (mortality) and growth (height increment) of Scots pine (Pinus sylvestris L.), English oak (Quercus robur L.), red oak (Quercus rubra L.), Norway maple (Acer platanoides L.) and Douglas fir (Pseudotsuga menziesii (Mirb.) Franco) three years after planting on agricultural land. The aim was also to assess the effect of different Alginite doses on nutrition concentrations in the assimilation apparatus of particular tree species.

\section{Material and methods}

\subsection{Description of the study area}

The effects and use of Alginite as supporting material for forest stands establishment on non-forest land was assessed at a relatively dry area near the Hovorčovice village north of Prague (Natural Forest Area/PLO 17 Polabí) in the Czech Republic. The site is located at GPS coordinates $\mathrm{N} 50^{\circ} 13.95^{\prime} \mathrm{E} 14^{\circ} 25.58^{\prime}$, and provisionally named "U Lomu". It is a former agricultural land on warm and moderately dry sites with an average annual temperature of $8-9^{\circ} \mathrm{C}$. The average annual precipitation is 500-600 $\mathrm{mm}$ and the expectation of dry vegetation season is $20-30 \%$. Higher temperatures and low precipitation in vegetation season are notably limiting factors on site (Tužinský et al. 2015). The research area is exposed to the west with modal eubasic to mesobasic cambisol on slate soil-forming substrate. The soil is deep to moderately deep with medium particle size distribution and good water storage capacity.

The research plot has a total area of $14,400 \mathrm{~m}^{2}$ and consists of 36 sub-plots designed $20 \times 20 \mathrm{~m}$. All sub-plots were established using dug-hole method in the spring of 2013 in the $1 \mathrm{~m}$ by $1 \mathrm{~m}$ spacing ( 400 pieces per plot). The whole research plotwas fenced and noweed trimming was applied. Selected tree species were following: Scots pine (Pinus sylvestris), and a line mix of English oak (Quercus robur), red oak (Quercus rubra) and Norway maple (Acer platanoides). Furthermore, Douglas-fir (Pseudotsuga menziesii) planting stock were planted in the $1 \mathrm{~m} \times 2 \mathrm{~m}$ spacing (200 trees per plot). Scots pine and Douglas-fir seedlings were two years old, all broadleaves were three years old while all seedlings used were bare rooted. Besides the control variant without any application of Alginite fertilizer (variant A), two variants with the application of $0.5 \mathrm{~kg}(\mathrm{~B})$ and $1.5 \mathrm{~kg}$ of Alginite (C) per planting point were planted. Alginite used in the study had following content of macroelements: Ca $15528 \mathrm{mg} / \mathrm{kg}$, Mg $1841 \mathrm{mg} / \mathrm{kg}, \mathrm{P} 42,9 \mathrm{mg} / \mathrm{kg}, \mathrm{K} 196 \mathrm{mg} / \mathrm{kg}$ and $\mathrm{N}$ total content was $0.207 \%$. All the variations ( 3 tree species choices by 3 variant choices) were established in 4 replications.

\subsection{Sample processing}

Tree heights were measured every autumn in the years 2013, 2014 and 2015 using height measuring instruments while mortality of individuals was also registered. Due to this fact the average height increments were calculated. In 2015, foliage samples (leaves or needles) were taken choosing 50 randomly selected trees (uniform distribution of random numbers by RNG/Excel) in each sub-plot in August from deciduous and coniferous species, respectively. Three composite samples were taken in each sub-plot for each tree species and for each variant. 
The analysis of assimilation apparatus was realized in the Tomáš laboratory, resident in VÚLHM Opočno according to standard methodologies (Zbíral 2001). The concentration of macroelements $(\mathrm{N}, \mathrm{P}, \mathrm{K}, \mathrm{Ca}, \mathrm{Mg})$ in the dry matter of foliage was contrasted with the classification limits according to Bergmann (1993).

The analyses were processed in the Statistica 12 software (StatSoft, Tulsa). All data were at first log transformed in order to meet the assumption of normal distribution (tested by Kolmogorov-Smirnov test). The differences between height increments of tree species were tested by one-way analysis of variance (ANOVA). Significant differences were consequently tested by post-hoc comparison Tukey's HSD tests. Unconstrained principal component analysis (PCA) in the CANOCO for Windows 4.5 program (Ter Braak \& Šmilauer 2002) was used to analyse relationships among number of plants, mortality, mean height, height increment, nutrient content in the assimilation apparatus, tree species and variants of Alginite application. Data were centred and standardized during the analysis. The results of the PCA analysis were visualized in the form of an ordination diagram constructed by the CanoDraw program (Ter Braak \& Šmilauer 2002).

\section{Results}

\subsection{Plantation mortality}

The values of seedlings mortality for individual tree species are listed in Table 1 below. The Alginite fertilization effect was most significantly exhibited immediately after planting, therefore already in 2013. Both smaller and larger doses had mostly positive impact on plants during the whole three-year period for Scots pine. For deciduous trees and Douglas fir, the application acted negatively in the first year, positive impact was found for English oak and Maple only in the B variant of Alginite application. In 2014 the situation was different for each tree species. Clearly positive reaction was shown by Red oak for both doses of Alginite. Douglas fir and English oak had lowest mortality in control variant A and Norway maple reacted positively to variant C. In 2015 the reaction was also mostly negative as in the first year after planting.

\subsection{Seedlings height increment}

For pine the plants significantly reacted to applications until second year after planting in smaller dose variant, but the reaction was negative (Table 2). In 2015 the results were significantly positive for both doses of Alginite application $(p<0.05)$. The differences in Douglas fir increment reactions were statistically significant in each year of measurements. The reaction was negative in both variants of Alginite application, the highest increment was measured in control variant $\mathrm{A}$.

All deciduous trees had the same trend of reaction in the first year after planting (Table 2). Statistically significant differences were registered for the $\mathrm{C}$ variant where the increment was lower than in the control A variant. For Red Oak and Norway maple we also recorded statistically significant negative reaction in B variant. In 2014 the situation was different. Statistically significant positive reaction was documented for Red oak and English oak trees in $\mathrm{C}$ variant of Alginite fertilization. Douglas fir reacted positively in both doses of Alginite. Statistically significantly lower increment was measured for Scotch pine in $\mathrm{C}$ variant and also for Norway maple in $\mathrm{B}$ variant. In general the trend of increment in 2014 was ambiguous. On the other hand, in 2015 a majority of planted trees showed the same reaction. The only exception was Douglas fir with smaller increment for $\mathrm{B}$ and $\mathrm{C}$ variant. All other tree species had statistically significantly higher increments in the $\mathrm{C}$ variant of Alginite fertilization, Scots pine reacted positively for both $\mathrm{B}$ and $\mathrm{C}$ variants (Table 2).

\subsection{Nutrients concentration in assimilation apparatus}

There were no statistically significant differences $(p>0.05)$ for any of the values. The nitrogen concentration was higher only in the English oak growing on both Alginite doses. Furthermore, only Scots pine growing on

Table 1. Evaluation of mortality in individual tree species reflecting Alginite applications.

\begin{tabular}{|c|c|c|c|c|c|}
\hline Tree species & Variants of Alginite & Number of trees planted - spring 2013 & 2013 & $\begin{array}{c}2014 \\
{[\%]}\end{array}$ & 2015 \\
\hline Pine & A & 1600 & 26.5 & 8.7 & 0.9 \\
\hline Pine & B & 1600 & 23.9 & 3.3 & 0.4 \\
\hline Pine & $\mathrm{C}$ & 1200 & 24.5 & 1.8 & 0.8 \\
\hline Oak & $\mathrm{A}$ & 562 & 5.5 & 6.4 & 4.8 \\
\hline Oak & $\mathrm{B}$ & 578 & 4.0 & 9.9 & 5.0 \\
\hline Oak & $\mathrm{C}$ & 722 & 7.9 & 9.8 & 5.4 \\
\hline Maple & $\mathrm{A}$ & 478 & 2.9 & 9.8 & 1.9 \\
\hline Maple & B & 522 & 1.9 & 10.0 & 3.3 \\
\hline Maple & $\mathrm{C}$ & 680 & 12.2 & 4.6 & 3.8 \\
\hline Red oak & A & 560 & 20.5 & 53.6 & 7.9 \\
\hline Red oak & B & 500 & 24.6 & 39.8 & 11.0 \\
\hline Red oak & $\mathrm{C}$ & 598 & 32.6 & 35.5 & 7.7 \\
\hline Douglas fir & $\mathrm{A}$ & 800 & 3.4 & 1.4 & 0.9 \\
\hline Douglas fir & B & 800 & 5.1 & 5.3 & 1.9 \\
\hline Douglas fir & $\mathrm{C}$ & 800 & 7.6 & 2.9 & 1.9 \\
\hline
\end{tabular}




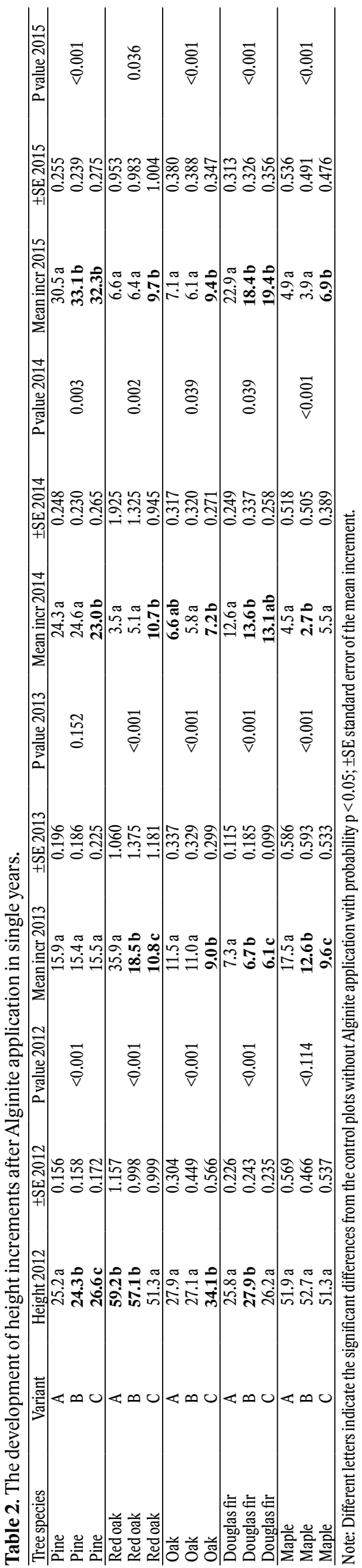

C variant showed positive response. For other species Alginite did not affect plants in nitrogen concentrations.

The most interesting results were found in phosphorus concentrations. The best results were performed by English oak and Norway maple on B and C variants. In addition, the Alginite application acted positively in red oak and Douglas fir but only for variant B, i.e. with smaller amount of fertilizer. Scots pine did not react to the stimulator and phosphorus values were even in all variants.

Diverse responses to Alginite were found in terms of potassium concentration. Only Douglas fir responded positively to the lower dose of Alginite. English oak and Scots pine were the only tree species showing positive reaction to the higher dose, i.e. $1.5 \mathrm{~kg}$ of Alginite. For red oak in both $B$ and $C$ variants the concentrations were smaller than control, Norway maple potassium concentration were smaller only in $B$ variant.

The least positive concentrations were detected for calcium. In this element only red oak responded positively on both variants. Furthermore, the positive effect of larger Alginite dose was found in Scots pine. For other planted tree species the concentration on both variants was smaller than control.

In contrast, for magnesium the situation was reverse. The concentration of this element was higher in Alginite treated variants compared to the control variant $\mathrm{A}$. The most positive reaction was found in both oaks where the concentration of magnesium was greater in both $\mathrm{B}$ and $\mathrm{C}$ variants. Maple responded positively only to $0.5 \mathrm{~kg}$ Alginite application. For Scots pine and Douglas fir only $\mathrm{C}$ variant with $1.5 \mathrm{~kg}$ of Alginite showed positive results.

\subsection{Relationships among seedling parameters, nutrient content and variants of Alginite application}

Results of the PCA analysis are presented in the form of the ordination diagram in Figure 1. The first ordination axis explained $41.1 \%$, the first two axes together $69.3 \%$ and the first four axes together explained $96.8 \%$ variability in the data. The first axis $x$ represented seedlings content of calcium and magnesium in the assimilation apparatus. The second axis y represented seedlings content of nitrogen and potassium in the assimilation apparatus. Height increment in 2014 and 2015 was positively correlated with content of nitrogen and mortality in the first year after planting, while these parameters were negatively correlated with potassium. Alginite application had a negative effect on mortality in the first year, but after rooting of seedlings Alginite had a positive significant impact on height growth in following years. Opposite height increment in 2013 had negative relationship with mortality in following two years. Height of seedling in 2013 was positively correlated with content of calcium and magnesium, while these parameters 
Table 3. Nutrient content in the assimilation apparatus of particular tree species in variants and recommended values according to Bergmann.

\begin{tabular}{|c|c|c|c|c|c|c|c|c|c|c|c|}
\hline Tree species & $\begin{array}{c}\text { Variant } \\
\text { of Alginite }\end{array}$ & $\mathrm{N}[\%]$ & $\pm \mathrm{SE}$ & $\mathrm{P}[\%]$ & $\pm \mathrm{SE}$ & $\mathrm{K}[\%]$ & $\pm \mathrm{SE}$ & $\mathrm{Ca}[\%]$ & $\pm \mathrm{SE}$ & $\operatorname{Mg}[\%]$ & $\pm \mathrm{SE}$ \\
\hline Oak & A & 1.75 & 0.1 & 0.17 & 0.01 & 0.57 & 0.02 & 2.25 & 0.08 & 0.24 & 0.02 \\
\hline Oak & B & 1.97 & 0.1 & 0.2 & 0.01 & 0.57 & 0.02 & 2.22 & 0.08 & 0.28 & 0.02 \\
\hline Oak & $\mathrm{C}$ & 1.81 & 0.1 & 0.18 & 0.01 & 0.58 & 0.02 & 2.08 & 0.08 & 0.25 & 0.02 \\
\hline Red oak & $\bar{A}$ & 1.55 & 0.07 & 0.16 & 0.02 & 0.65 & 0.06 & 1.93 & 0.15 & 0.21 & 0.01 \\
\hline Red oak & B & 1.49 & 0.07 & 0.17 & 0.02 & 0.58 & 0.06 & 1.95 & 0.15 & 0.23 & 0.01 \\
\hline Red oak & $\mathrm{C}$ & 1.34 & 0.07 & 0.15 & 0.02 & 0.62 & 0.06 & 1.97 & 0.15 & 0.23 & 0.01 \\
\hline Oak Bergmann & - & $2-3$ & - & $0.15-0.3$ & - & $1-1.5$ & - & $0.3-1.5$ & - & $0.15-0.3$ & - \\
\hline Maple & $\bar{A}$ & 1.59 & 0.09 & 0.29 & 0.05 & 0.67 & 0.04 & 2.3 & 0.15 & 0.26 & 0.03 \\
\hline Maple & B & 1.46 & 0.09 & 0.35 & 0.05 & 0.67 & 0.04 & 2.28 & 0.15 & 0.27 & 0.03 \\
\hline Maple & $\mathrm{C}$ & 1.55 & 0.09 & 0.31 & 0.05 & 0.65 & 0.04 & 2.12 & 0.15 & 0.26 & 0.03 \\
\hline Maple Bergmann & - & $1.7-2.2$ & - & $0.15-0.25$ & - & $1-1.5$ & - & $0.3-1.5$ & - & $0.15-0.3$ & - \\
\hline Pine & $\mathrm{A}$ & 1.66 & 0.03 & 0.14 & 0.04 & 0.59 & 0.01 & 0.34 & 0.01 & 0.11 & 0.01 \\
\hline Pine & B & 1.63 & 0.03 & 0.14 & 0.04 & 0.59 & 0.01 & 0.33 & 0.01 & 0.11 & 0.01 \\
\hline Pine & $\mathrm{C}$ & 1.69 & 0.03 & 0.14 & 0.04 & 0.6 & 0.01 & 0.35 & 0.01 & 0.12 & 0.01 \\
\hline Pine Bergmann & - & $1.4-1.7$ & - & $0.14-0.3$ & - & $0.4-0.8$ & - & $0.25-0.6$ & - & $0.1-0.2$ & - \\
\hline Douglas fir & $\bar{A}$ & 1.29 & 0.04 & 0.13 & 0.03 & 0.66 & 0.02 & 0.38 & 0.01 & 0.08 & 0.01 \\
\hline Douglas fir & B & 1.11 & 0.04 & 0.14 & 0.03 & 0.67 & 0.02 & 0.33 & 0.01 & 0.08 & 0.01 \\
\hline Douglas fir & $\mathrm{C}$ & 1.12 & 0.04 & 0.13 & 0.03 & 0.65 & 0.02 & 0.35 & 0.01 & 0.09 & 0.01 \\
\hline D. fir Bergmann & - & $1.1-1.7$ & - & $0.12-0.30$ & - & $0.6-1.1$ & - & $0.2-0.6$ & - & $0.1-0.25$ & - \\
\hline
\end{tabular}

Note: The higher nutrient contents in variants with Alginite compared to control plots (without fertilizer) are highlighted. Values according to Bergmann describe the first content value as a threshold of sufficiency, the second value as a threshold of excess; \pm SE standard error of the mean.

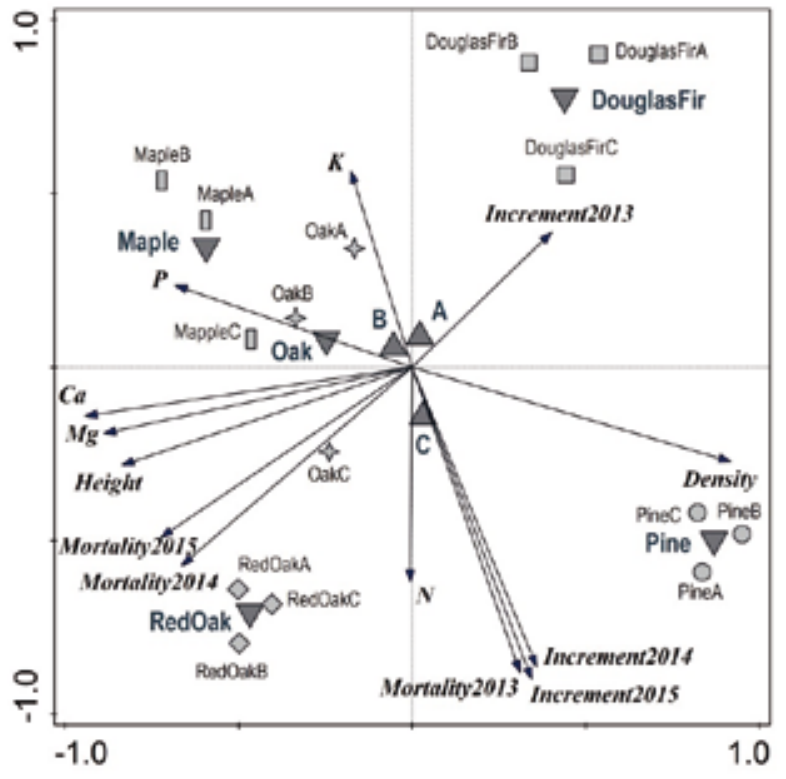

Fig. 1. Ordination diagram showing results of PCA analysis of relationships number of seedlings at planting (Density), heights at planting (Height), tree mortality (Mortality) and height increments (Increment) in 2013, 2014 and 2015 and nutrient content in the assimilation apparatus $(\mathrm{N}, \mathrm{K}, \mathrm{Ca}, \mathrm{P}$, $M g$ ), tree species (Maple, Douglas Fir, Oak, Red Oak, Pine) and variants of Alginite application $(A, B, C)$; Small codes: $\bullet, \downarrow, \mathbf{\square}, \downarrow$, indicate tree species with variants of Alginite application; Large codes: $\boldsymbol{\Delta}, \boldsymbol{\nabla}$ indicate tree species or variants of Alginite application.

were negatively correlated with number of seedlings. The contribution of mean increment in 2013 was relatively small. The Alginite application (variants A, B, C) showed low significance to mutual relationships among seedling mortality, mean increment and nutrient content in the assimilation apparatus compared to great differences among tree species. Differences of variants of Alginite application were remarkable especially for English oak and maple as marks of each record are relatively distant from one another whereas marks for Red oak and pine are fairly close together in the diagram. Comparing variants of tree species with different Alginite application there were differences among one another, where variants with broadleaves with higher mortality and content of mostly nutrients ( $\mathrm{Ca}, \mathrm{Mg}$ and $\mathrm{P}$ ) occupied the left part of the diagram, while higher height increment of seedlings one year after planting and density were typical for coniferous (right part). Overall Alginite application had positive higher effect on height growth of seedlings than mortality. Differences between variant A (without Alginite) and $\mathrm{B}$ (0.5 kg Alginite) were smaller compared to variant $\mathrm{C}$ $1.5 \mathrm{~kg}$ Alginite), while the $C$ variant had the greatest effect on height growth.

\section{Discussion}

Reduction of trees mortality in the first year immediately after planting is one of the reasons why fertilizers are used in forestry. There are already publications focusing on plant mortality causes on forest land (Barbeito et al. 2012) and therefore raises the question of optimal ways of supporting newly planted trees. Those are for instance nutrient loaded seedlings (Scott et al. 2016), water retaining polymers in tree nursery substrates (Navroski et al. 2016) or different fertilization approaches (Huotari et al. 2008; Pärn et al. 2009; Ferreiro-Dominguez et al. 2011; Yang et al. 2016). Support for planting of forest trees on agricultural land with unbalanced conditions is often necessary (Kupka et al. 2015) and it becomes increasingly important with regard to further expected afforestation of agricultural land (Hatlapatková \& Podrázský 2011). Positive impact of Alginite on the seedling survival in the 
first year after plantation on this site were confirmed and published (Tužinský et al. 2015) and a similar attempt in "U Hnojiště", approximately $3 \mathrm{~km}$ away from the locality "U Lomu" (Kupka et al. 2015) also showed positive effects. Definitely positive results in mortality through the three years were only recorded on pine plots, especially in 2014 . In this year we can cogitate a positive impact of Alginite water absorbing capability, while the spring (Apri l- June) months were dry (Czech Hydrometeorological Institute Prague Kbely) which might have resulted in high mortality in A variant without Alginite application. Other tree species showed rather indifferent response to fertilization via mortality.

The height increment of seedlings, i.e. their growth, is another factor reflecting the response to the fertilizer application. In the past, the effect of fertilizers on different kinds of trees using wood ash or ash obtained from peat was tested (Huotari et al. 2008; Kikamägi et al. 2014; Pärn et al. 2009). These works investigate development of the seedlings height during the first 3 years after planting; a positive influence of fertilizing by the ashes, however, was studied only on forest land. Sewage sludge is another fertilizer. These studies evaluated sparsely wooded sites on agricultural land, where forestry and pasture were combined. Evaluating the impact of sewage sludge in combination with adding nitrogen confirmed the increased height increment in red oak seedlings during the first four years after planting (Ferreiro-Dominguez et al. 2011). Positive effect of nitrogen on height increment of seedlings in 2014 and 2015 follows also from results of PCA analysis. Furthermore Alginite application had a negative effect on mortality in the first year after planting, but in following years Alginite had a positive significant impact on height growth, probably due to rooting of seedlings through used fertiliser. Another paper, which compared the use of sewage sludge in comparison with the control and the area fertilized with mineral fertilizers (by $500 \mathrm{~kg}$ to $8 \% \mathrm{~N}-24 \% \mathrm{P}_{2} \mathrm{O}_{5}-16 \% \mathrm{~K}_{2} \mathrm{O}$ per hectare) also confirmed the positive effect of sewage sludge on the height of seedlings (Rigueira-Rodríguez et al. 2010). On the other hand, the use of sewage sludge in combination with lime has not been confirmed as a positively functioning agent in the height of the seedlings (Mosquera-Losada et al. 2012). Alginite influence with positive results in height increment has only been evaluated one year after planting (Kupka et al. 2015; Tužinský et al. 2015). The three-year planting evaluation showed a positive trend in height increment overall. In the first year the results were somewhat negative, but this might be caused by slow growth of the root system. The second year after planting was heterogeneous throughout tree species while mostly broadleaves reacted positively. The explanation could be different root system growth rapidity. In the last year of measurements the effect of Alginite application was positive for almost all tree species. Due to these results we can suspect positive Alginite influence on agricultural land plantations. Only Douglas fir reaction was negative. Positive results are comparable with the results of sewage sludge (Ferreiro-Dominguez et al. 2011; Rigueira-Rodriguez et al. 2010).

One of the main factors that influence the growth of forest trees is the nutrient content in assimilation organs (Šrámek et al. 2009; Truparová \& Kulhavý 2011; Vacek et al. 2009). None of the variants with different Alginite applications showed statistical significance in the nutrient content in dry matter of the assimilation apparatus. Only slightly higher values were found for each of the measured nutrients, with the highest for $\mathrm{P}$ and $\mathrm{Mg}$, in at least one of the species. Those were always recorded in one of the variants with Alginite application. This indicates a positive effect of Alginite fertilization on forest plants for both $\mathrm{P}$ and $\mathrm{Mg}$ have a major role in growth and formation of seedlings (Materna 1963; Vacek et al. 2006). Those contents might also reach higher values after a longer period of growth. Furthermore, a trend of higher concentrations of elements in deciduous trees has been observed (Hagen-Thorn et al. 2004; Šrámek et al. 2009), most strikingly in magnesium. The actual supply of elements in the dry matter of the assimilation apparatus on afforested agricultural land according to Bergmann (1993) showed values approaching, and often exceeding the threshold of excess. In all deciduous trees, lack of nitrogen and potassium was found, which can be caused by the nature of the soil or the soil type and local conditions overall.

\section{Conclusions}

The results showed ambiguous trend of Alginite utilization on mortality of seedlings, positive effect was discovered only for Scots pine in the whole measured period, other planted trees reacted mostly negative for both doses of Alginite. The positive reaction was recorded in the height increment of most tree species in the third year after planting. One of the reasons could be a slow roots growth through used fertiliser. Agricultural land afforestation is of growing importance and we need to pay more attention to improving the soil environment and support the growth of stands. Alginite application is a way to effectively support plantations of specific tree species, and therefore, more research should be devoted to this topic in the coming years.

\section{Acknowledgement}

This article was written within the project NAZV QJ1320122 "Optimizing management of afforestation of agricultural land in relation to increasing retention potential of landscape" and also with the Czech University of Life Sciences Prague, Faculty of Forestry and Wood Sciences (IGA no. A01_16 at the Department of Silviculture). 


\section{References}

Anthelem, F., Grossi, J. L., Brun, J. J., Didier, L., 2001: Consequences of green alder expansion on vegetation changes and arthropod communities removal in the northern French Alps. Forest Ecology and Management, 145:57-65.

Balcar, V., Kacálek, D., Kuneš, I., Dušek, D., 2011:Effect of soil liming on European beech (Fagus sylvatica L.) and sycamore maple (Acerpseudoplatanus L.) plantations. Folia Forestalia Polonica, series A - Forestry, 53:85-92.

Barbeito, I., Dawes, M., Rixen, Ch., Senn, J., Bebi, P., 2012: Factors driving mortality and growth at tree line: a 30-year experiment of 92000 conifers. Ecology, 93:389-401.

Bergmann, W., 1993: Ernährungstörungen bei Kulturpflanzen. Entstehung, visuelle und analytische Diagnose 3edn. Gustav Fisher Verlag, Jena.

Ter Braak, C., J., F., Šmilauer, P., 2002: CANOCO reference manual and CanoDraw for Windows user's guide: software for canonical community ordination (version 4.5), Microcomputer Power, Ithaca, New York.

Campbell, J., Lobell, D., Genova, R., Field, C., 2008: The global potential of bioenergy on abandoned agriculture lands. Environmental Science \& Technology, 242:5791-5794.

Černý, Z., Lokvenc, T., Neruda, J., 1995: Zalesňování nelesních půd. Praha, Institut výchovy a vzdělávání Ministerstva zemědělství, $55 \mathrm{p}$.

Ferreiro-Domínguez, N., Rigueiro-Rodríguez, A., Mosquera-Losada, M. R., 2011: Response to sewage sludge fertilisation in a Quercus rubra L. silvopastoral system: Soil, plant biodiversity and tree and pasture production. Agriculture, Ecosystems and Environment, 141:49-57.

Gömöryová, E., Vass, D., Pichler, V., Gömöry, D., 2009: Effect of aginite amendment on microbial activity and soil water content in forest soils. Biologia, 64:585588.

Gruber, F., Nickl, L., 2000: Influence of a sand soil plough base on the growth of Douglas fir (Pseudotsuga menziesii (Mirb.) Franco). Allgemeine Forst und Jagdzeitung, 171:21-26.

Hagen-Thorn, A., Armolaitis, K., Callesen, I., Stjernquist, I., 2004: Macronutrients in tree stems and foliage: a comparative study of six temperate species planted at the same stands. Annals of Forest Science 61:489-498.

Hatlapatková, L., Podrázský, V., Vacek, S., 2006: Výzkum v lesních porostech na bývalých zemědělských půdách v oblasti Deštného a Neratova v PLO 25 Orlické hory. In: Zalesňování zemědělských půd, výzva pro lesnický sektor. Sborník referátů KPL FLE ČZU v Praze, p. 15-24.

Hatlapatková, L., Podrázský, V., 2011: Obnova vrstev nadložního humusu na zalesněných zemědělských půdách. Zprávy lesnického výzkumu, 56:228-234.
Henebry, G. M., 2009: Carbon in idle croplands. Nature, 457:1089-1090.

Huotari, N., Tillman-Sutela, E., Pasanen, J., Kubine, E., 2008: Ash-fertilization improves germination and early establishment of birch (Betula pubescens Ehrh.) seedings on a cut-away peatland. Forest Ecology and Management, 255:2870-2875.

Kádár, I., Ragályi, P., Murányi, A., Radimszky, L., Gajdó, A., 2015: Effect of Gérce alginit on the fertility of an acid sandy soil. Agrokémia és Talajtan, 64:437-452.

Kacálek, D., Bartoš, J., 2002: Problematika zalesňování neproduktivních zemědělských pozemků v České republice. Praha, FLD ČZU, p. 39-45.

Kaplan, J., Krumhardt, K., Zimmermann, N., 2009: The prehistoric and preindustrial deforestation of Europe. Quaternary Science Reviews, 28:3016-3034.

Kikamägi, K., Ots, K., Kuznetsova, T., Pototski, A., 2014: The growth and nutrients status of conifers on ashtreated cutaway peatland. Trees, 28:53-64.

Kulich, J., Valko, J., Obernauer, D., 2001: Perspective of exploitation of alginit in plant nutrition. Journal of Central European Agriculture, 2:3-4.

Kuneš, I., Baláš, M., Špulák, O., Kacálek, D., Balcar, V., Šesták, J. et al., 2011: Stav výživy smrku ztepilého jako podklad pro zvážení potřeby přihnojení listnáčů ajedle vnášených do jehličnatých porostů. Zprávylesnického výzkumu, 56:36-43.

Kuneš, I., Balcar, V., Benešová, T., Baláš, M., Zadina, J., Zahradník, D. et al., 2009: Influence of pulverized limestone and amphibolite mixture on the growth performance of Alnus incana (L.) Moench plantation on an acidified mountain site. Journal of Forest Science, 55:469-476.

Kuneš, I., Balcar, V., Čížek, M., 2004: Influence of amphibolite powder and Silvamix fertiliser on Norway spruce plantation in conditions of air polluted mountains. Journal of Forest Science, 50:366-373.

Kupka, I., Prknová, H., Holubík, O., Tužinský, M., 2015: Účinek přípravků na bázi řas na ujímavost a odrůstání výsadeb lesních dřevin. Zprávy lesnického výzkumu, 60:24-28.

Materna, J., 1963: Výživa a hnojení lesních porostů. Praha, STN, $227 \mathrm{p}$.

Miltner, S., Kupka, I., 2016: Silvicultural potential of northern red oak and its regeneration - Review. Journal of Forest Science, 62:145-152.

Ministerstvo zemědělství České republiky, 2015:Zpráva o stavu lesa a lesního hospodářství České republiky v roce 2014. Praha, MZe ČR, 196 p.

Mosquera-Losada, M. R., Rigueiro-Rodriguez, A., Ferreiro-Dominguez, N., 2012: Residual effect of lime and sewage sludge input on soil fertility and tree and pasture production in a Pinus radiata D. Don silvopastoral system established in a very acidic soil. Agriculture, Ecosystems and Environment, 161:165-173.

Navroski, M.C., Araujo, M. M., Pereira, M. D., Fior, C.S., 2016: Influence of a water retaining polymer on the characteristics of a commercial substrate for the production of forest seedlings. Interciencia, 41:357-361. 
Pärn, H., Mandre, M., Tilk, M., 2009: Changes in the Growth of Silver Birch (Betula pendula Roth) and Black Alder (Alnus glutinosa [L.] Gaertn.) Seedlings on Peat Soil Fertilisation with Wood and Peat Ashes. Baltic Forestry, 15:168-176.

Podrázský, V., 1994: Liming of pine stands on sandy soils in the area of Týniště nad Orlicí (East Bohemia). In: Matějka, K. (ed.): Investigation of the forest ecosystems and of forest damage. Lowland and submountain forests and monitoring of the forest status. Proceedings of the workshop. Kostelec nad Černými lesy, 5. - 7. 4. 1993. České Budějovice, Scientific Pedagogical Publishing, p. 202-212.

Podrázský, V., Remeš, J., Ulbrichová, I., 2003: Biological and chemical amelioration effects on the localities degraded by bulldozer site preparartion in the Ore Mts. - Czech Republic. Journal of Forest Science, 49:141-147.

Podrázský, V., Štěpáník, R., 2002: Vývoj půd na zalesněných zemědělských plochách - oblast LS Český Rudolec. Zprávy lesnického výzkumu, 47:5356.

Podrázský, V., Ulbrichová, I., Kuneš, I., Folk, P., 2004: Vliv olše zelené na stav lesních půd ve vyšších nadmořských výškách. Zprávy lesnického výzkumu, 49:29-31.

Podrázský, V., 2006a: Fertilization as an ameliorative measure - examples of the research at the Faculty of Forestry and Environment CUA in Prague. Journal of Forest Science, 52:58-64.

Podrázský, V., 2006b: Effect of controlled liming on the soil chemistry on the immission clear-cut. Journal of Forest Science, 52:28-34.

Rigueiro-Rodríguez, A. A., Ferreiro-Domínguez, N., Mosquera-Losada, M. R., 2010: The effects of fertilization with anaerobic, composted and pelletized sewage sludge on soil, tree growth, pasture production and biodiversity in a silvopastoral system under ash (Fraxinus excelsior L.). Grass and Forage Science, 65:248-259.

Rowney, M., 2015: Broken Arbour: "The Ruined Cottage" and Deforestation. European Romantic Review, 26:719-741.

Scott, K. M., Snively, A. E. K., Landhäuser, S. M., Pinno, B. D., 2016: Nutrient loaded seedlings reduce the need for field fertilization and vegetation management on boreal forest reclamation sites. New Forest, 47:393-410.

Skaloš, J., Engstová, B., Trpáková, I., Šantrůčková, M., Podrázský, V., 2012: Long-term changes in forest cover 1780-2007 in central Bohemia, Czech Republic. European Journal of Forest Research, 131:871-884.

Szabó, L. P., 2004: Characterization of alginite humic acid content. PERMEA 2003, Membrane Science and Technology Conference of Visegrad Countries, Tatranské Matliare, 7.-11.9. 2003, p. 85-91.
Šindelář, J., Frýdl, J., 2006: Hlavní směry a cíle aktivit spojených se zalesňováním nelesních půd v České republice. Zalesňování zemědělských půd, výzva pro lesnický sektor. Kostelec nad Černými lesy, 17. 1. 2006, Praha, ČZU a Jíloviště-Strnady, VÚLHM VS Opočno: 33-38.

Špulák, O., 2006: Příspěvek k historii zalesňování zemědělských půd v České republice. In:Zalesňování zemědělských půd, výzva pro lesnický sektor. Sborník referátů, p. 15-24.

Špulák, O., Kacálek, D., 2011: Historie zalesňování nelesních půd na území ČR. Zprávy lesnického výzkumu, 56:49-57.

Šrámek, V., Lomský, B., Novotný, R., 2009: Hodnocení obsahu a zásoby živin v lesních porostech - literární přehled. Zprávy lesnického výzkumu, 54:307-315.

Truparová, S., Kulhavý, J., 2011: Výživa smrkových porostů na vápněných plochách s různou intenzitou probírkového zásahu v Moravskoslezských Beskydech. Zprávy lesnického výzkumu, 56:178-188.

Tužinský, M., Kupka, I., Podrázský, V., Prknová, H., 2015: Influence of the mineral rock alginite on survival rate and rate-growth of selected tree species on agricultural land. Journal of Forest Science, 61:399405.

Vacek, S., Podrázský, V., Hejcman, M., Remeš, J., 2006: Effect of Mg fertilization on yellowing disease of Norway spruce at higher elevations of the Šumava Mts., Czech Republic. Journal of Forest Science, 52:474-481.

Vacek, S., Hejcman, M., Semelová, V., Remeš, J., Podrázský, V., 2009: Effect of soil chemical properties on growth, foliation and nutrition of Norway spruce stand affected by yellowing in the Bohemian Forest Mts., Czech Republic. European Journal of Forest Research, 128:367-375.

Vacek, S., Hejcman, M., 2012: Natural layering, foliation, fertility and plant species composition of a Fagus sylvatica stand above the alpine timberline in the Giant (Krkonoše) Mts., Czech Republic. European Journal of Forest Research, 131:799-810.

Vacek, S., Hejcmanová, P., Hejcman, M., 2012: Vegetative reproduction of Picea abies by artificial layering at the ecotone of the alpine timberline in the Giant (Krkonoše) Mountains, Czech Republic. Forest Ecology and Management, 263:199-207.

Vacek, S., Vacek, Z., Bulušek, D., Putalová, T., Sarginci, M., Schwarz, O. et al., 2015: European Ash (Fraxinus excelsior L.) dieback: Disintegrating Forest in the Mountains Protected areas, Czech Republic. Austrian Journal of Forest Science, 132:203-222.

Vacek, Z., Vacek, S., Podrázský, V., Král, J., Bulušek, D., Putalová, T. et al., 2016: Structural diversity and production of alder stands on former agricultural land at high altitudes. Dendrobiology, 75:31-44. 
Vass, D., Konečný, V., Elečko, M., Milička, J., Snopková, P., Šucha, V. et al., 1997: Alginit - Nový zdroj slovenského nerudného surovinového potenciálu (ložisko Pinciná). Mineralia Slovaca, 29:1-39.

Vass, D., Konečný, V., Elečko, M., Kozáč, J., Molnár, J., Zakovič, M., 1998: Ložisko diatomitu v bazaltovom mare pri Jelšovci a možnosti jeho využitia. Mineralia Slovaca, 30:333-356.

Williams, M., 2000: Dark ages and dark areas: global deforestation in the deep past. Journal of Historical Geography, 26:28-46.
Yang, A. R., Hwang, J., Cho, M. S., Son, Y., 2016: The effect on fertilization on early growth of konara oak and Japanese zelkova seedlings planted in a harvested pitch pine plantation. Journal of Forestry Research, 27: 863-870.

Zbíral, J., 2001: Porovnání extrakčních postupů pro stanovení základních živin v půdách ČR. Brno, Ústřední kontrolní a zkušební ústav zemědělský, $205 \mathrm{p}$.

Internet sources:

Czech Hydrometeorological Institute Prague Kbely, available online from: www.in-pocasi.cz 